Int. Archs Allergy appl. Immun. 1975;49:I-XII

\title{
Contents, Vol. 49, 1975
}

\section{No. 1-2}

Westphal, O. (Freiburg-Zähringen): Bacterial Endotoxins. The Second Carl Prausnitz Memorial Lecture

1

Aas, K. (Oslo): Clinical and Experimental Aspects of Standardization and Puri fication of Allergen 44

Yman, L. (Uppsala): Allergen Assay and Extract Potency Estimation

Berrens, L. (Utrecht): Plural Actions of Allergens. A Problem in Purification and Standardization 63

Weeke, B. and Løwenstein, H. (Copenhagen): Quantitative Immunoelectrophoresis (QIE) Used in Analysis of Allergen Extracts and Diagnosis of Allergy 74

Hirschfeld, J. (Stockholm): Interpretation of Immunodiffusion Data 79 Laurell, A.-B.; Mârtensson, U, and Sjöholm, A.G. (Lund): Complement Components in Hereditary Angioedema and Chronic Urticaria 86 Rosenthal, R.R.; Bruce, C.A.; Lichtenstein, L.M., and Norman, P.S. (Balti more, $\mathrm{Md}$ ): The Role of Inhalation Challenge 89 Løwenstein, H.; Nielsen, L., and Weeke, B. (Copenhagen): Purification of Timothy Pollen Allergens Followed by Quantitative Immunoelectrophoresis 95 Mygind, N.; Weeke, B., and Ullman, S. (Copenhagen): Quantitative Determi nation of Immunoglobulins in Nasal Secretion 99

Siraganian, R. P. (Bethesda, Md.): Automated Histamine Release. A Method for in vitro Allergy Diagnosis 108

Grant, J. A.; Dupree, E., and Goldman, A. S. (Galveston, Tex.): Release of Chemical Mediators from Both Allergic and Non-Allergic Human Leukocytes Ill Sobotka, A. K.; Valentine, M. D.; Benton, A.W.; Adkinson, N. F. jr., and Lichtenstein, L. M. (Baltimore, Md.): Hymenoptera Sensitivity. Diagnostic and Therapeutic Studies 115

Bundgaard, H. (Copenhagen) and Weck, A. L. de (Bern): The Role of AminoReactive Impurities in Acetylsalicylic Acid Allergy 119

Glazer, I. and Leventon, G. (Tel Aviv): Topical Treatment of Hay Fever with Disodium Cromoglycate (DSCG) Solution 125

Ishizaka, T. (Baltimore, Md.): Mechanisms for Sensitization of Human Basophil Granulocytes 129

Lichtenstein, L.M. (Baltimore, Md.): Sequential Analysis of the Allergic Re sponse: Cyclic AMP, Calcium and Histamine 143

Diamant, B. (Copenhagen): Energy Production in Rat Mast Cells and its Role for Histamine Release 155

Morrison, D.C.; Roser, J.F.; Cochrane, C.G., and Henson, P.M. (La Jolla, Calif.): Two Distinct Mechanisms for the Initiation of Mast Cell Degranulation 172 Foreman, J. C. and Gomperts, B. D. (London): The Relationship between Ana- 
IV

Contents

phylactic Histamine Secretion and the Permeability of the Mast Cell Membrane

to Calcium 179

Diamant, B. and Patkar, S. A. (Copenhagen): Stimulation and Inhibition of

Histamine Release from Isolated Rat Mast Cells. Dual Effects of the Ionophore A23187 183

Johansen, T. and Chakravarty, N. (Odense): Adenosine Triphosphate Content

of Mast Cells in Relation to Histamine Release Induced by Anaphylactic

Reaction 208

Schmutzler, W. and Freundt, G. P. (Aachen): The Effect of Glucocorticoids

and Catecholamines on Cyclic AMP and Allergic Histamine Release in Guinea

Pig Lung 209

Dawson, W. and Sweatman, W. J. F. (Windlesham, Surrey): Probable Role of

Prostaglandins in Asthma 213

West, G. B. (London): Is There a Link between Resistance of Rats to Dextran and their Failure to Produce Reaginic Antibodies? 217

Levy, D. A. (Baltimore, Md.): Allergenic Activity of Proteins from Mice 219

Lee, W. Y. and Sehon, A. H. (Winnipeg, Man.): Specific Suppression of Reaginic Antibodies in Mice 222

Strannegård, Ö. and Lindholm, L. (Göteborg): Effect of Graft-versus-Host

Reactions on Reagin Production in Mice 225

Miller, J. F. A. P. (Melbourne, Victoria): T-Cell Control of B-Cell Respon siveness 230

Turk, J.L. and Parker, D. (London): Modulation of T-Lymphocyte Function by B Lymphocytes in Delayed Hypersensitivity 241

Weck, A.L. de (Bern): Molecular Mechanisms of T and B Lymphocyte Triggering 247

Ishizaka, K. (Baltimore, Md.): Cellular Mechanisms of IgE Antibody Response 255

Milgrom, F.; Gewirtz, A., and Abeyounis, C.J. (Buffalo, N.Y.): Skin Reactions

with Transplantation Antibodies

271

Parker, D.; Katz, S.I., and Turk, J.L. (London): Demonstration of Suppressor

Cells in Delayed Hypersensitivity by B Lymphocytes 276

Polak, L. (Basel): Suppressor Cells in Different Types of Unresponsiveness to

Dinitrochlorobenzene (DNCB) Contact Sensitivity in Guinea Pigs 281

No. 3

Wyczolkowska, J. and Maslinski, Cz. (Lodz): Inhibition by Nicotinamide of an Homologous PCA Reaction and Antigen-Induced Histamine Release from

Rat Peritoneal Mast Cells 285

Ströbel, G. and Staab, H.-J. (Tubingen): A New Reliable Method for Evaluation of Foot Pad Swelling as an Experimental in vivo Immune Phenomenon 293

Walker, D. M. and Dolby, A. E. (Cardiff): Effect of Disodium Cromoglycate on Lymphocyte Response to Antigen and Mitogen 303

Tufveson, G. (Uppsala): Spontaneous Rosette-Forming Cells in the Chicken.

Tissue distribution, binding characteristics and bursa dependency 310

Escajadillo, C. and Binns, R. M. (Cambridge): Rosette Formation of Pig T

Lymphocytes with Sheep Erythrocytes. Further Data 325 
Contents

$\mathrm{V}$

Glick, B.; Perkins, W. D.; Rosse, C, and Schwarz, M. R. (Seattle, Wash.):

Comparison of Lymphocyte Populations Bearing Surface Immunoglobulins in

Avian Bone Marrow, Bursa, Spleen and Thymus 332

Kramár, J. (Omaha, Nebr.): Pharmacodynamic Study of the Capillaries of Normal and Allergic (Atopic) Subjects 341

Leslie, G.A.; Correa, R.H.L., and Holmes, J.N. (New Orleans, La.): Structure and Biological Functions of Human IgD. IV. Ontogeny of Human Serum Immunoglobulin D (IgD) as Related to IgG, IgA and IgM 350

Koltai, M.; Blazsó, G.; Minker, E.; Lonovics, J., and Ottlecz, A. (Szeged): Anaphylactoid-Inflammation-Promoting Factor. An Insulin-Induced Factor Derived from Non-Sensitized Lymphocytes Increases Anaphylactoid Inflam mation in Rats 358

Yeoh, T.-S.; Yap, E.-H.; Singh, M., and Ho, B.-Ch. (Singapore): Drug Inhibition of Anaphylactic Histamine Release from Peritoneal Cells of Rats Infected with Toxocara canis 371

Patterson, R. and Harris, K. E. (Chicago, Ill.): Arterial and Muscle Oxygen

Tension in Experimental Models of Asthma. Experimental Models of Asthma 381

Buchala, A.J. and Laszt, L. (Fribourg): Studies on an Immunologic Method for the Diagnosis of Varicose Veins 391

Ottesen, E.A.; Smith, T.K., and Kirkpatrick, Ch.H. (Bethesda, Md.): Immune

Response to Trichinella spiralis in the Rat. I. Development of Cellular and

Humoral Responses during Chronic Infection 396

Short Communication

Godfrey, H. P. (Copenhagen): Seasonal Variation of Induction of Contact Sen

sitivity and of Lymph Node T Lymphocytes in Guinea Pigs 411

News Items 415

No. 4

Evans, D.P.; Marshall, P.W., and Thomson, D.S. (Macclesfield): Inhibition of Immediate

Hypersensitivity Reactions in the Rat by ICI 74, 917 and Di-sodium Cromoglycate.

Tachyphylaxis and Cross-Reactivity in vivo and in vitro 417

Maur, K. von; Turk, A.; Stevens, M. B.; Adkinson, N. F., jr., and Lichtenstein,

L.M. (Baltimore, Md.): Penicillin Hypersensitivity in Systemic Lupus Ery-

thematosus 428

Svennerholm, A.-M. (Göteborg): Experimental Studies on Cholera Immunization.

4. The Antibody Response to Formalinized Vibrio cholerae and Purified Endo-

toxin with Special Reference to Protective Capacity 434

Fossan, G.O. and Tönder, O. (Bergen): Natural Antibodies in Human Cerebro-

spinal Fluid to Rabbit Erythrocytes 453

Yamaguchi, H.; Takeuchi, H.; Torikata, C, and Kageyama, K. (Tokyo):

Experimental Pulmonary Fibrosis Induced by Soluble Immune Complex and

$60 \%$ Oxygen Atmosphere 464

VI

Contents 
Renoux, M.L.; Montis, G. de; Roche, A., and Marcelli, D. (Paris): Binding of Human IgE Immunoglobulin to Rat Mast Cells. A Study by Means of Three Independent Techniques 478

Barker, W. W.; Engelhart, J. J.; Mulder, I., and Hoedemaeker, P. J.: (Gro-

ningen): Lymphokines in Sensitized Rats. I. Migration Inhibitory Factor(s)

from Specifically Stimulated Thymocytes in vitro 491

Friedrich, W.; Lazary, S.; Geczy, C, and Weck, A.L. de (Berne): Lympho

kines. I. Use of Insoluble Concanavalin A for the Production of Migration

Inhibitory Factor in Guinea Pig Lymphocyte Cultures 504

Krogh, H.K.; Maeland, J.A., and Tønder, O. (Bergen): Specificity of Antigens

in Aqueous Phenol Extracts of Skin Examined by Means of Guinea Pig and

Rabbit Immune Sera 519

Salerno, A.; Byfield, P.; Borsellino, A.; Albano, S.; Bella via, A., and

Caruso, C. (Palermo): Regulation of Antibody Formation in Chickens

Escaping from Tolerance to Human Serum Albumin 530

FÉsüs, L.; Muszbek, L., and Csaba, B. (Debrecen): Evidence of Fibrinogen De

gradation in Rat Anaphylaxis 540

Zeromski, J.; Górny, M. K.; Wruk, M., and Sapula, J. (Chodziez): Behaviour

of Local and Systemic Immunoglobulins in Patients with Lung Cancer 548

Short Communications Grove, D.I.; Burston, T.O., and Forbes, I.J. (Woodville): Serum IgE

Levels

in Paraproteinaemia 564

Marusic, M.; Allegretti, N., and Culo, F. (Zagreb): Yoshida Ascites Sarcoma

Grown in Mice $\quad 568$

No. 5

Izumi, S.; Penrose, J.M.; More, D.G., and Nelson, D.S. (Sydney): Further

Observations on the Immunological Induction of DNA Synthesis in Mouse

Peritoneal Macrophages. Role of Products of Activated Lymphocytes 573

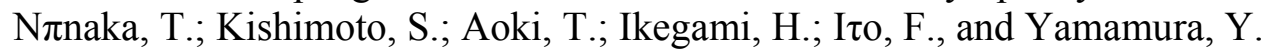

(Osaka): Skin Reaction, Inhibition of Macrophage Migration, and Lympho

cyte Transformation with Tuberculin Active Peptide (TAP) and Arabino-

galactan Obtained from Tubercle Bacilli 585

Lertora, J.J.L.; Gomez-Perez, F.J., and Leslie, G.A. (Portland, Oreg.): Struc

ture and Biological Functions of Human IgD. V. Insulin Antibodies of the

IgD Class in Sera from some Diabetic Patients 597

Bröcker, E.-B. and Müller-Ruchholtz, W. (Kiel): Presence and Kinetics of

Sensitized Cells in Different Tissue Compartments 607

Ahlstedt, S.; Jodal, U., and Hanson, L.Å. (Göteborg): Amount and Avidity of Antibody to

Escherichia coli O Antigen Measured with the Ammonium Sulfate Precipitation Technique in

Children with Urinary Tract Infections ... 615

Broom, B.C. and Alexander, P. (Sutton, Surrey): Mast Cell and Anaphylactic

Antibody Responses in Inbred Rats to Syngeneic Fibrosarcomas 627

Contents

VII

Berrens, L. and van Rijswijk-Verbeek, J. (Utrecht): Fibrinolytic Activity of

Allergenic Preparations: An Artefact Due to Enzyme Contamination 
Fujita, Y.; Wicher, K.; Wypych, J.I.; Reisman, R.E., and Arbesman, C.E. (Buffalo, N. Y.): In vitro Reaction of Antibodies to Ragweed. II. Quantitative Determination of Non-IgE Antibodies Interferring in a Radioallergosorbent Test 636

Marshall, R. (Oxford): Disruption of Isolated Peritoneal Mast Cells of the Rat by Human Serum and that by other Species 647

Symons, D. B. A. and Binns, R. M. (Cambridge): Immunoglobulin-Bearing Lym phocytes: Their Demonstration in Adult Sheep and Ontogeny in the Sheep Fetus 658

Vadas, M.A.; Miller, J.F.A.P.; Gamble, J., and Whitelaw, A. (Melbourne): A Radioisotopic Method to Measure Delayed Type Hypersensitivity in the Mouse. I. Studies in Sensitized and Normal Mice $\quad 670$

Miller, J.F.A.P.; Vadas, M.A.; Whitelaw, A., and Gamble, J. (Melbourne): A Radioisotopic Method to Measure Delayed Type Hypersensitivity in the Mouse. II. Cell Transfer Studies 693

Short Communication

Sawicki, J.E. and Catanzaro, P.J. (Washington, D.C.): Selective Macrophage Cytotoxicity of Carrageenan in vivo 709

Varia 715

No. 6

Wells, J.H. and Cain, W.A. (Oklahoma City, Okla.): Relationship between the Response to Complete Freund Adjuvant, Phytohemagglutinin, and Subsequent Tumor Growth in Mice 717

Fujita, Y.; Wypych, J.I.; Wicher, K.; Reisman, R.E., and Arbesman, C.E. (Buffalo, N. Y.): In vitro Reaction of Antibodies to Ragwed. I. Radioimmunoassay for Measuring Antibody Levels 724

Gupta, S. and Grieco, M.H. (New York, N. Y.): Rosette Formation with Mouse Erythrocytes: Probable Marker for Human B Lymphocytes 734

Roberts, I.M.; Whittingham, S.; Cowling, D.C., and Mackay, I.R. (Mel bourne, Vic.): Antigen-Binding Cells in Human Fetal Liver 743

Rooijen Van, N. (Amsterdam): Immune Complexes in the Spleen. Replacement of Immune Complexes Trapped in Spleen Follicles by New Immune Com plexes from the Circulation 754

Yamaguchi, H.; Takeuchi, H.; Torikata, C.; Ashizawa, M.; Shiobara, H, and Ishii, Y. (Tokyo): Experimental Osteomyelitis Induced by Repeated Ad ministration of Soluble Immune Complexes: Consideration of the Fundamental Pathogenesis of Osteomyelitis $\quad 763$ Burka, J.F. and Eyre, P. (Guelph, Ont.): Modulation of the Formation and Release of Bovine SRS-A in vitro by several Anti-Anaphylactic Drugs ..... 774 Mirza, A.M.; Perera, M.G.; Maccia, C.A.; Dziubynskyj, O.G., and BernVIII

Contents

stein, I.L. (Cincinnati, Ohio): Leukocyte Migration Inhibition in Nickel Der matitis 782 
Possanza, G.J.; Bauen, A., and Stewart, P.B. (Pointe Claire, Que.): In vitro Antagonism of the Mediators of Allergy by a Benzopyrano-Benzopyran Carboxylic Acid PR-D-92-EA 789

Lehrer, S.B.; Vaughan, J.H., and Tan, E.M. (La Jolla, Calif.): Adjuvant Activity of the Hístamine-Sensitizing Factor of Bordetella pertussis in Different Strains of Mice 796

Orren, A. and Dowdle, E. B. (Cape Town): Effects of Allergy, Intestinal Hel minthic Infestation and Sex on Serum IgE Concentrations and Immediate Skin Hypersensitivity in Three Ethnic Groups 814 Fink, J. N.; Moore, V. L., and Barboriak, J. J. (Milwaukee, Wise.): Cell-Mediated Hypersensitivity in Pigeon Breeders 831

Farid, N.R.; Barnard, J.; Kutas, C; Noel, E.P., and Marshall, W. H. (St.John's, Newfoundland): HL-A Antigens in Graves' Disease and Hashi moto's Thyroiditis 837

Wiedermann, G.; Müller, M.M.; Förster, O., and Stemberger, H. (Vienna): Influence of Surface Hapten Density of Sheep Red Blood Cells on the Hemolytic of Blocking Activity of IgG Antibodies 843

Author Index

855

Molecular and Cellular Aspects of Allergy

Edited by

B. Diamant (Copenhagen), P. Kallós (Helsingborg), H. Rorsman (Lund)

and G. B. West (Epsom)

With 98 figures and 50 tables

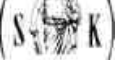

$19 \backslash$ Wy 75

S. Karger · Basel · München · Paris · London · New York · Sydney

Transactions of the Collegium Internationale Allergologicum

6th Symposium in London, September 1964. Recent Advances in Allergy and Immunology.

Edited by D. Harley (London), P. Kallós (Helsingborg) and G. B. West (London). IV+140 p., 39

fig., 16 tab., 1965. (Separatum vol. 28, No. 1-3 International Archives of

Allergy and Applied Immunology.) ISBN No. 3-8055-0736-4. 7th Symposium in Tel-Aviv, 1968. Recent Trends in Experimental and Clinical Allergy. Edited by R. R. A. Coombs (Cambridge), D. Harley (London), P. Kallós (Helsingborg) and G. B. West (Carshalton, Surrey). $\mathrm{X}+218$ p., 80 fig., 47 tab., 1969. (Separatum vol. 36, No. 1-2 International Archives of Allergy and Applied Immunology.) ISBN No. 3-8055-

0748-8. 8th Symposium in Montreux, 1970. Cellular and Molecular Mechanisms of CellMediated Allergic Reactions Chemistry of Allergens. Edited by P. Kallós (Helsingborg), A. de Weck (Berne) and G. B. West (Epsom, Surrey). IV + 236 p., 70 fig., 30 tab., 1971. (Separatum vol. 41, No. 1 International Archives of Allergy and Applied Immunology.) ISBN No. 3-8055-1191-4. 9th Symposium in London, 1972. The Theoretical and Practical Aspects of Allergic Disorders. Edited by Darien Parker (London), J. L. Turk (London) and G. B. West (Epsom, Surrey). IV + 329 p., 85 fig., 41 tab., 1973. (Separatum vol. 45, No. 1-2 International Archives of Allergy and Applied Immunology.) ISBN No. 3-8055-1605-3. 
S. Karger · Basel · München · Paris · London · New York · Sydney Arnold Böcklín-Strasse 25, CH-4011 Basel (Switzerland)

All rights, including that of translation into other languages, reserved.

Photomechanic reproduction (photocopy, microcopy) of this volume or parts thereof without special permission of the publishers is prohibited.

(C) Copyright 1975 by S. Karger AG, Verlag für Medizin und Naturwissenschaften, Basel

Printed in Switzerland by Buchdruckerei National-Zeitung AG, Basel

ISBN 3-8055-2166-9

Contents

Westphal, O. (Freiburg-Zähringen): Bacterial Endotoxins. The Second Carl Praus-

nitz Memorial Lecture 1

A as, K. (Oslo): Clinical and Experimental Aspects of Standardization and Puri

fication of Allergen 44

Yman, L. (Uppsala): Allergen Assay and Extract Potency Estimation 55

Berrens, L. (Utrecht): Plural Actions of Allergens. A Problem in Purification and

Standardization

63

Weeke, B. and Løwenstein, H. (Copenhagen): Quantitative Immunoelectro-

phoresis (QIE) Used in Analysis of Allergen Extracts and Diagnosis of Allergy 74

Hirschfeld, J. (Stockholm): Interpretation of ímmunodiffusion Data 79

Laurell, A.-B.; Mårtensson, U., and Sjöholm, A. G. (Lund): Complement

Components in Hereditary Angioedema and Chronic Urticaria 86

Rosenthal, R. R.; Bruce, C. A.; Lichtenstein, L. M., and Norman, P. S. (Balti

more, Md.): The Role of Inhalation Challenge $\quad 89$

Løwenstein, H.; Nielsen, L., and Weeke, B. (Copenhagen): Purification of

Timothy Pollen Allergens Followed by Quantitative Immunoelectrophoresis. . 95

Mygind, N.; Weeke, B., and Ullman, S. (Copenhagen): Quantitative Determina

tion of Immunoglobulins in Nasal Secretion 99

Siraganian, R. P. (Bethesda, Md.): Automated Histamine Release. A Method for

in vitro Allergy Diagnosis 108

Grant, J. A.; Dupree, E., and Goldman, A. S. (Galveston, Tex.): Release of

Chemical Mediators from Both Allergic and Non-Allergic Human Leukocytes Ill

Sobotka, A. K.; Valentine, M. D.; Benton, A. W.; Adkinson, N. F. jr., and

Lichtenstein, L. M. (Baltimore, Md.): Hymenoptera Sensitivity. Diagnostic

and Therapeutic Studies 115

Bundgaard, H. (Copenhagen) and Weck, A. L. de (Bern): The Role of Amino-

Reactive Impurities in Acetylsalicylic Acid Allergy 119

Glazer, I. and Leventon, G. (Tel Aviv): Topical Treatment of Hay Fever with

Disodium Cromoglycate (DSCG) Solution 125

Ishizaka, T. (Baltimore, Md.): Mechanisms for Sensitization of Human Baso-

phil Granulocytes 129

IV Contents

Lichtenstein, L. M. (Baltimore, Md.): Sequential Analysis of the Allergic Respon

se: Cyclic AMP, Calcium and Histamine 143

Diamant, B. (Copenhagen): Energy Production in Rat Mast Cells and its Role

for Histamine Release 155

Morrison, D. C; Roser, J. F.; Cochrane, C. G., and Henson, P. M. (La Jolla, 
Calif.): Two Distinct Mechanisms for the Initiation of Mast Cell Degranulation 172 Foreman, J. C. and Gomperts, B. D. (London): The Relationship between Anaphylactic Histamine Secretion and the Permeability of the Mast Cell Membrane to Calcium 179

Diamant, B. and Patkar, S. A. (Copenhagen): Stimulation and Inhibition of Histamine Release from Isolated Rat Mast Cells. Dual Effects of the Ionophore A23187 183

Johansen, T. and Chakravarty, N. (Odense): Adenosine Triphosphate Content of Mast Cells in Relation to Histamine Release Induced by Anaphylactic Reaction 208

Schmutzler, W. and Freundt, G. P. (Aachen): The Effect of Glucocorticoids and Catecholamines on Cyclic AMP and Allergic Histamine Release in Guinea Pig Lung 209

Dawson, W. and Sweatman, W. J. F. (Windlesham, Surrey): Probable Role of Prostaglandins in Asthma 213

West, G. B. (London): Is There a Link between Resistance of Rats to Dextran and their Failure to Produce Reaginic Antibodies? 217

Levy, D. A. (Baltimore, Md.): Allergenic Activity of Proteins from Mice 219

Lee, W. Y. and Sehon, A. H. (Winnipeg, Man.): Specific Suppression of Reaginic Antibodies in Mice 222

Strannegård, Ö. and Lindholm, L. (Göteborg): Effect of Graft-versus-Host

Reactions on Reagin Production in Mice 225

Miller, J. F. A. P. (Melbourne, Victoria): T-Cell Control of B-Cell Respon siveness 230

Turk, J. L. and Parker, D. (London): Modulation of T-Lymphocyte Function by B Lymphocytes in Delayed Hypersensitivity 241

Weck, A. L. de (Bern): Molecular Mechanisms of T and B Lymphocyte Triggering 247

Ishizaka, K. (Baltimore, Md.): Cellular Mechanisms of IgE Antibody Response 255

Milgrom, F.; Gewirtz, A., and Abeyounis, C. J. (Buffalo, N. Y.): Skin Reactions

with Transplantation Antibodies 271

Parker, D.; Katz, S. I., and Turk, J. L. (London): Demonstration of Suppressor

Cells in Delayed Hypersensitivity by B Lymphocytes 276

Polak, L. (Basel): Suppressor Cells in Different Types of Unresponsiveness to

Dinitrochlorobenzene (DNCB) Contact Sensitivity in Guinea Pigs 281 